\title{
Enhancement of TRAlL-Mediated Apoptosis by Genistein in Human Hepatocellular Carcinoma Hep3B Cells: Roles of p38 MAPK Signaling Pathway
}

\author{
Cheng-Yun Jin', Cheol Park', Sang-Eun Park ${ }^{3}$, Sang-Hoon $\mathrm{Hong}^{3}$ and Yung Hyun Choil, ${ }^{1,4}$ \\ ${ }^{1}$ Department of Biomaterial Control (BK21 program) and Blue-Bio Industry Regional Innovation Center, Dongeui University, Busan 614-714, \\ Korea \\ ${ }^{2}$ Medical Research Institute, Chungbuk National University College of Medicine, Cheongiu 361-763, Korea \\ Departments of ${ }^{3}$ Internal Oriental Medicine and ${ }^{4}$ Biochemistry and Research Institute of Oriental Medicine, Dongeui University College at \\ Oriental Medicine, Busan 614-052, Korea
}

Received August 12, 2011 /Revised November 1, 2011 /Accepted November 2, 2011

\begin{abstract}
Tumor necrosis factor-related apoptosis-inducing ligand (TRAIL) can selectively induce apoptosis in many types of transformed cells; however, some human hepatocellular carcinoma cells are particularly resistant to the effects of TRAIL. Although genistein, a natural isoflavonoid phytoestrogen, has been shown to have pro-apoptotic activity against human cancer cell lines, little is known about the mechanism of genistein in terms of TRAIL-induced apoptosis. In the present study, it was investigated whether or not combined treatment with genistein and TRAIL synergistically induced apoptosis in Hep3B hepatocarcinoma cells. Results indicate that treatment with TRAIL in combination with nontoxic concentrations of genistein sensitized TRAIL-resistant Hep3B cells to TRAIL-induced apoptosis, which was associated with mitochondrial dysfunction. Further, the inhibition of p38 mitogen-activated protein kinase (MAPK) activation markedly decreased genistein and TRAIL-induced cell viability and apoptosis by enhanced truncation of Bid, increase of pro-apoptotic Bax, decrease of anti-apoptotic $\mathrm{Bcl}-2$, and release of cytochrome $c$ from mitochondria to cytoplasm. Activation of caspases and degradation of poly (ADP-ribose) polymerase induced by the combined treatment was also markedly increased by the inhibition of $338 \mathrm{MAPK}$, through the mitochondrial amplification step. In conclusion, our data suggest that genistein sensitizes TRAIL-induced-apoptosis via p38 MAPK-dependent pathway.
\end{abstract}

Key words : TRAIL, genistein, apoptosis, p38 MAPK

\section{서 론}

Tumor necrosis factor (TNF) family의 일종인 TNF-related apoptosis-inducing ligand (TRAIL)는 최근 정상세포에서는 세포독성을 전혀 나타내지 않는 반면 다양한 종류의 암세포에 서 apoptosis를 일으킬 수 있는 능력이 있음이 밝혀진 이후 가장 기대되는 항암치료제의 일종으로 인식되어왔다[1,3]. 이 러한 TRAIL의 apoptosis 유도 활성은 세포막에 존재하는 TRAIL 수용체와 caspase-8의 발현 정도에 따라 감수성이 달라 질 수 있는데[2,35], TRAIL이 death receptor (DR) 4 및 5와의 결합에 의하여 caspase-8이 활성화되면 caspase-3 및 -7과 같은 effector caspase가 활성화되면서 세포 내 apoptosis 유도 신호 가 개시된다[34]. 하지만 최근 인체 간암세포를 포함한 많은 암세포들이 TRAIL 저항성을 획득함으로서 TRAIL에 의한 apoptosis 신호가 무력화될 수 있음이 보고되어져 오고 있다 [38]. 아마도 TRAIL 저항성의 획득은 DRs와 pro-apoptotic 단

\footnotetext{
*Corresponding author

Tel : +82-51-850-7413, Fax : +82-51-853-4036.

E-mail : choiyh@deu.ac.kr
}

백질인 Bax의 돌연변이나, inhibitor of apoptosis (IAP) family 에 속하는 XIAP 및 $\mathrm{CIAP}$ 와 같은 단백질의 과발현 등에 의한 것으로 밝혀지고 있다[23,33]. 그러나 최근 TRAIL 저항성 $\mathrm{Hep3B}$ 간암세포에서 브루콜리나 십자화과 식물에 많이 함유 되어 있는 isothiocyanate 일종인 sulforaphane이 TRAIL에 의 한 apoptosis 유도를 증진시킬 수 있음이 보고된 바 있는데, 이는 sulforaphane에 의하여 생성되는 reactive oxygen species에 의하여 조절되는 DR5의 발현 증대에 의한 현상으로 밝혀졌다[17]. 이는 TRAIL 저항성 암세포의 효율적인 apoptosis 유도에 천연물의 복합처리가 유용하게 응용될 수 있음을 보여 주는 한 예에 해당된다. 특히 과도한 세포독성을 보이지 않는 범위에서의 TRAIL과 천연물의 복합처리에 의한 apoptosis 유도는 TRAIL 내성 극복과 동시에 안전한 항암전략으로 인식될 수 있기 때문에 이와 연관된 분자생물학적 기전 연구 가 최근 활발하게 이루어지고 있다.

한편 식이성 isoflavonoids의 섭취가 높은 집단에서 특정 암의 발병율이 낮은 것은 이미 잘 알려진 현상이며[8], 암의 예방 차원에서 이들 isoflavonoids의 활용성이 매우 높을 수 있음을 의미한다. Genistein은 특히 대두에 다량으로 함유되어 
있는 isoflavone compound의 일종으로 다양한 세포 내 신호 전달을 조절하는 하는 것으로 잘 알려져 왔다[16,31]. 특히 다 양한 암세포의 증식 억제, 분화 유도, 세포주기 교란 및 apoptosis 유도 등에 관한 genistein은 기전 연구가 꾸준하게 이루 어져 왔다 $[9,29,30,32]$. 최근 본 연구실에서도 그동안의 genistein 항암효능 기전연구를 토대로[6,7,27], TRAIL 저항성 극복 가능성을 조사한 바 있다. 본 연구실의 최근 결과에 의하면 genistein은 TRAIL 저항성 위암세포에서 caspase-3의 활성 증 대를 통하여 apoptosis 유도 상승효과를 보였으며[13], TRAIL 저항성 간암세포에서 genistein은 Bid의 truncation을 촉진시 킴으로서 apoptosis 개시 신호를 활성화시켰음을 보고한 바 있다[15]. 아울러 genistein은 TRAIL 저항성 간암세포에서 TRAIL 매개 apoptosis 유도가 p38 mitogen-activated protein kinase (MAPK) signaling pathway의 억제를 통하여 이루어 질 수 있을 가능성을 보고한 바 있다[14,36]. 이러한 결과들은 TRAIL 저항성 암세포의 apoptosis 유도를 위하여 genistein이 매우 효율적으로 사용될 수 있음을 보여주는 것이다.

세포 내 신호전달계의 핵심적인 역할을 하는 $\mathrm{mi}-$ togen-activated protein kinases (MAPKs) 중에서 p38 MAPK 신호 경로는 많은 암세포에서 활성화되어 있기 때문에 항암제 에 대한 암세포의 apoptosis 저항성을 일으키는 한 요인으로 알려져 있다. 따라서 p38 MAPK 경로의 억제는 항암활성을 가지는 약물이나 천연물에 의한 암세포의 증식 억제 및 항암 활성을 증대시킬 수 있는 것으로 보고되어져 오고 있다 $[10,11,26]$. 예를 들어, 방광암세포에서 interleukin-8에 의한 TRAIL 유도 apoptosis의 억제가 p38 MAPK 경로와 연관되어 있었으며[2], apoptosis 저항성을 가지는 유방암 및 간암세포 에서 TNF 또는 TRAIL에 의한 apoptosis 유도는 p38 MAPK signaling 활성 저하에 의하여 이루어졌음이 보고된 바 있다 [36,37]. 그러나 TRAIL 저항성 극복과 연관된 p38 MAPK의 역할에 대한 자세한 기전이 보고된 바는 없다. 따라서 본 연구 에서는 TRAIL 저항성을 가지는 Hep3B 간암세포에서 TRAIL 에 의한 apoptosis 활성 증대에 genistein이 효율적으로 사용 될 수 있는지, 또한 그 과정에서 $\mathrm{p} 38 \mathrm{MAPK}$ 가 직접적으로 관 여하고 있는지의 여부에 관하여 조사하였다.

\section{재료 및 방법}

\section{실험재료 및 항체}

본 연구에 사용된 propidium iodide (PI), 4,6-diamidino-2-phenylindole (DAPI), 3-(4,5-Dimethyl-2-thiazolyl)-2,5-diphnyl-2H-tetrazolium bromide (MTT) 및 5,5 V, 6,6 V-tetrachloro-1,1 V,3,3 V-tetraethyl-imidacarbocyanine iodide (JC-1)은 Sigma (St Louis, MO)에서 구입하였으며, RPMI1640 배지 및 fetal bovine serum (FBS)는 Invitrogen Corp. (Carlsbad, CA)과 GIBCO-BRL (Gaithersburg, $\mathrm{MD}$ )에서
각각 구입하였다. Bcl-2, Bax, Bid, cytochrome $\mathcal{C}$, poly (ADP-ribose) polymerase (PARP), caspase-3, -8 및 -9 항체는 Santa Cruz Biotechnology (SantaCruz, CA)에서 구입하였고, $\beta$ -actin은 Sigma에서, peroxidase-labeled donkey anti-rabbit 및 heepanti-mouse immunoglobulin은 Amersham Life Science Corp. (Arlington Heights, IL)에서 구입하였다.

\section{세포배양}

Hep3B 인체 간암세포는 American Type Culture Collection (Rockville, $\mathrm{MD}$ )에서 분주 받아 $10 \% \mathrm{FBS}, 1 \%$ 의 penicillin 및 streptomycin (Biofluids, Rockville, $\mathrm{MD}$ )이 포함 된 RPMI- 1640 배지를 사용하여 $37^{\circ} \mathrm{C}, 5 \% \mathrm{CO}_{2}$ 조건 하에서 배양하였다. Genistein (Sigma)과 TRAIL (KOMA Biotech Inc, Seoul, Korea)은 각각 $\mathrm{DMSO}$ 와 $\mathrm{PBS}$ 에 적정 농도로 녹여 배지 에 희석하여 처리하였다.

MTT assay

다양한 조건에서의 $\mathrm{Hep} 3 \mathrm{~B}$ 세포 증식 억제의 비교를 위하여 MTT assay를 실시하였다. 이를 위해 적정 조건에서 Hep3B 세포를 배양 후 배지를 제거하고 MTT를 $0.5 \mathrm{mg} / \mathrm{ml}$ 농도로 희석하여 $200 \mu 1$ 씩 분주하고 $37^{\circ} \mathrm{C}$ 에서 3 시간 동안 다시 배양하 였다. 배양이 끝난 다음 MTT 시약을 제거하고 dimethylsulfoxide (DMSO, Sigma)를 $1 \mathrm{ml}$ 씩 분주하여 well에 생성된 formazin을 모두 녹인 후 96 well plate에 200 씨씩 옮겨서 ELISA reader (Molecular Devices, Sunnyvale, CA)로 $540 \mathrm{~nm}$ 에서 흡광도를 측정하였다. 측정은 모두 세 번을 하였으며, 그에 대한 평균값과 표준 오차를 MicrosoftEXCEL program을 사용 하여 분석하였다.

\section{DAPI staining에 의한 세포핵의 형태 관찰}

Apoptosis가 유발되었을 경우 특이적으로 나타나는 핵의 형태적 변화를 관찰하기 위하여 준비된 세포를 $3.7 \%$ formaldehyde 용액으로 고정 후, $2.5 \mu \mathrm{g} / \mathrm{ml}$ 의 DAPI 용액을 처리하 여 상온에서 15 분간 염색하였다. 염색이 끝난 후 DAPI 용액을 충분하게 세척하고 mounting solution을 처리한 후 형광 현미 경(Carl Zeiss, Germany)을 이용하여 400배의 배율로 핵의 형 태 변화를 관찰하였다.

\section{Flow cytometry 분석}

Apoptosis 유도의 정도를 정량적으로 분석하기 위하여 준 비된 세포들을 CycleTEST PLUS DNA REAGENT Kit (Becton Dickinson, San Jose, CA)를 이용하여 고정 및 염색을 하여 $4^{\circ} \mathrm{C}$, 암실에서 30 분 동안 반응을 시켰다. 반응시킨 세포를 35-mm mesh를 이용하여 단일세포로 분리한 후 FACSCalibur (Becton Dickinson)를 적용시켜 형광반응에 따른 Cellular DNA content 및 histogram을 CellQuest software 및 ModiFit 
LT (Becton Dickinson) 프로그램을 이용하여 분석하였다.

\section{DNA 단편화 분석}

Apoptosis 유발의 또 다른 증거인 DNA 단편화 현상의 분 석을 위하여 준비된 세포에 lysis buffer $[5 \mathrm{mM}$ Tris- $\mathrm{HCl}(\mathrm{pH}$ 7.5), $5 \mathrm{mM}$ EDTA, 0.5\% Triton X-100]를 첨가하여 상온에서 30 분간 lysis 시킨 다음 $14,000 \mathrm{rpm}, 4^{\circ} \mathrm{C}$ 에서 20 분간 원심 분리 하여 상층액을 회수하였다. 회수된 상층액에 proteinase $\mathrm{K}$ solution (Sigma)을 $0.5 \mathrm{mg} / \mathrm{ml}$ 의 농도로 처리하여 $50^{\circ} \mathrm{C}$ 에서 3시 간 동안 반응시킨 후 phenol : chloroform : isoamyl alcohol 혼합 용액(25: $24: 1, \mathrm{Sigma})$ 을 첨가하고 30 분간 회전교반 시킨 다음 $14,000 \mathrm{rpm}$ 에서 10 분간 원심 분리하였다. 여기서 얻어진 상층액에 적정량의 isopropanol (Sigma)과 $5 \mathrm{M} \mathrm{NaCl}$ 를 첨가하여 $4^{\circ} \mathrm{C}$ 에서 24 시간 동안 반응시킨 후, $14,000 \mathrm{rpm}$, $4^{\circ} \mathrm{C}$ 에서 30 분간 원심 분리시켜 상층액을 제거하고 DNA pellet을 추출하였다. DNA pellet에 RNase A가 적당량 들어있는 TE buffer를 이용하여 녹인 후, 6X gel loading dye (Bioneer, Daejeon, Korea)를 섞어 주었다. 마지막으로 $1.6 \%$ agarose gel 을 만들어서 1 시간 동안 $50 \mathrm{~V}$ 로 전기영동 시킨 후 ethidium bromide (EtBr, Sigma)로 염색하여 DNA 단편화 현상을 확인 하였다

\section{Mitochondrial membrane potential (MMP, $\left.\Delta \psi_{\mathrm{m}}\right)$ 분석}

다양한 조건에서 배양된 $\mathrm{Hep3B}$ 세포의 $\mathrm{MMP}$ 변화 정도를 측정하기 위하여 $2,000 \mathrm{rpm}$ 으로 5 분간 원심 분리하여 상층액 을 버리고 세포들만 모은 다음 $500 \mu \mathrm{l}$ 의 $\mathrm{PBS}$ 를 첨가하여 충분 히 섞은 후, $10 \mu \mathrm{M} \mathrm{JC}-1$ 을 처리하여 20 분 동안 $37^{\circ} \mathrm{C}$ 에서 반응 시켰다. 반응시킨 세포를 $2,000 \mathrm{rpm}$ 으로 원심 분리하여 상층 액을 버리고 다시 $500 \mu \mathrm{l}$ 의 차가운 $\mathrm{PBS}$ 를 첨가하고 $35 \mathrm{~mm}$ mesh를 이용하여 단일세포로 분리한 후 FACSCalibur에 적용 시켜 $\mathrm{MMP}$ 의 변화정도를 분석하였다.

\section{Western blot analysis에 의한 단백질 발현의 분석}

준비된 세포에 적당량의 lysis buffer [25 mM Tris-Cl $(\mathrm{pH}$ 7.5), $250 \mathrm{mM} \mathrm{NaCl}, 5 \mathrm{mM}$ EDTA, 1\% NP-40, $1 \mathrm{mM}$ phenymethylsulfonyl fluoride (PMSF), $5 \mathrm{mM}$ dithiothreitol (DTT)]를 첨가하여 $4{ }^{\circ} \mathrm{C}$ 에서 1 시간 동안 반응시킨 후, $14,000 \mathrm{rpm}$ 으로 30 분간 원심 분리하여 상층액에 있는 총 단백질을 분리하였 다. 상층액의 단백질 농도는 Bio-Rad 단백질 정량 시약 (Bio-Rad, Hercules, CA)의 사용방법에 따라 정량 한 다음 동 량의 Laemmli sample buffer (Bio-Rad)를 섞어서 sample을 만들었다. 동량의 sample을 sodium dodecyl sulphate (SDS)-polyacrylamide gel을 이용하여 전기영동으로 분리한 후, nitrocellulose membrane (Schleicher and Schuell, Keene, $\mathrm{NH}$ )으로 electroblotting에 의해 전이시켰다. 분리된 단백질이 전이된 nitrocellulose membrane을 5\% skim milk를 처리하여
비특이적인 단백질들에 대한 blocking을 실시하고 1차 항체를 처리하여 상온에서 2 시간 이상 또는 $4^{\circ} \mathrm{C}$ 에서 over night 시킨 다음 PBS-T로 세척하고 처리된 1차 항체에 맞는 2차 항체 (PBS-T로 1:1500으로 희석하여 사용)를 사용하여 상온에서 1 시간 정도 반응시켰다. 반응이 끝난 후 암실에서 Enhanced Chemiluminoesence (ECL) slution (Amersham Life Science Corp.)을 적용시킨 다음 X-ray film에 감광시켜 특정단백 질의 발현 변화를 분석하였다.

\section{결 과}

Hep3B 세포에서 genistein에 의한 TRAIL 유도 apoptosis 의 촉진

TRAIL에 의하여 유도되는 apoptosis에 미치는 genistein의 영향을 조사하기 위하여 $100 \mathrm{ng} / \mathrm{ml}$ 의 TRAIL이 처리된 Hep3B 세포에 다양한 농도의 genistein을 처리한 후 flow cytometry 분석을 실시하였다. Fig. $1 \mathrm{~A}$ 에 나타낸 결과에서 알 수 있듯이 $100 \mathrm{ng} / \mathrm{ml}$ 의 TRAIL이 단독 처리된 경우 apoptosis 가 유발된 세포의 빈도에 해당되는 sub-G1기에 속하는 세포의 빈도가 약 $7.1 \%$ 정도였으나, 12 및 $25 \mu \mathrm{M}$ 의 genistein을 동시 에 처리하였을 경우, 19.2 및 32.1\%로 apoptosis 유도의 정도가 매우 증가되었다. 그러나 $25 \mu \mathrm{M}$ 의 genistein이 단독으로 처리 된 경우 apoptosis 유도의 정도는 $2.0 \%$ 정도로서 대조군과 매 우 유사하여 Hep3B에 세포독성을 보이지 않는 genistein 처리 농도 범위에서 genistein은 TRAIL에 의한 apoptosis 유도를 매우 효과적으로 증가시켰음을 알 수 있었다. 또한 이러한 현 상은 DAPI 염색에 의한 세포 핵의 형태변화 관찰에서도 유사 한 결과를 얻었다(Fig. 1C).

한편 미토콘드리아는 apoptosis 유도 과정에 가장 중심이 되는 세포 내 소기관으로서 세포 내·외 신호 전달의 매개체 로 작용하며, 다양한 인자들의 발현 변화에 의하여 apoptosis 유도에 직접적으로 관여한다. 이러한 genistein의 TRAIL에 의 한 apoptosis 유도 증대에 미토콘드리아 기능 손상이 연관되 어 있는지의 여부를 조사하기 위하여 $\mathrm{MMP}$ 의 손실 정도를 조사한 결과, $100 \mathrm{ng} / \mathrm{ml}$ 의 TRAIL이 단독 처리된 경우 $\mathrm{MMP}$ 손실의 정도가 $8 \%$ 정도였음에 비하여 12 및 $25 \mu \mathrm{M}$ 의 genistein이 동시에 처리된 경우 $\mathrm{MMP}$ 손실 정도가 22 및 $41 \%$ 로 매우 증가되었으나, genistein 단독 처리군에서의 $\mathrm{MMP}$ 손실 정도는 대조군과 유사하게 나타났다(Fig. 1B).

Genistein에 의한 TRAIL 유도 apoptosis의 촉진에 미치 는 PI3K/Akt 및 MAPKs pathway의 영향

Fig. 1에서 관찰된 genistein에 의한 TRAIL 유도 apoptosis 의 촉진 효과와 연관된 phosphoinositide-3 kinase (PI3K)/Akt 및 MAPKs pathway의 역할을 조사하기 위하여, Hep3B 세포 에 genistein과 TRAIL의 복합 처리 1시간 전에 c-Jun N-termi- 
(A)

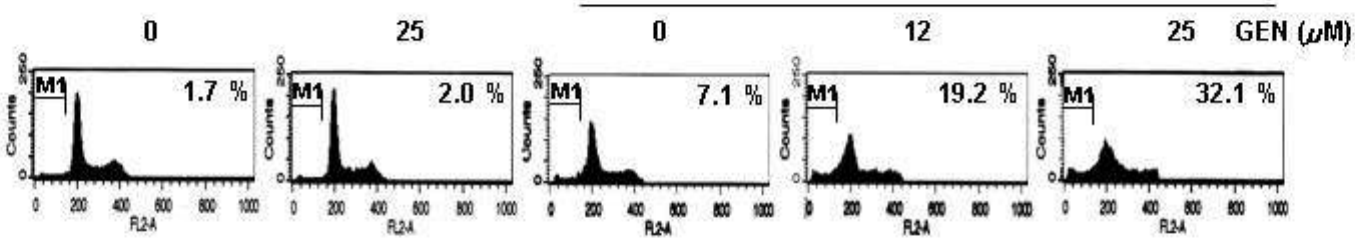

(B) + TRAIL (100 ng/ml)
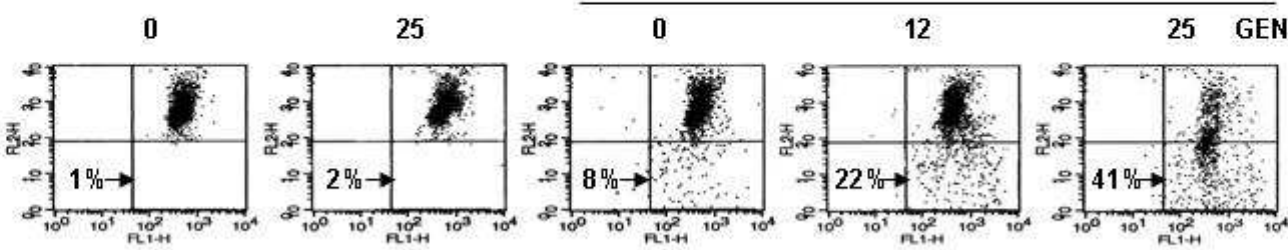

(C)

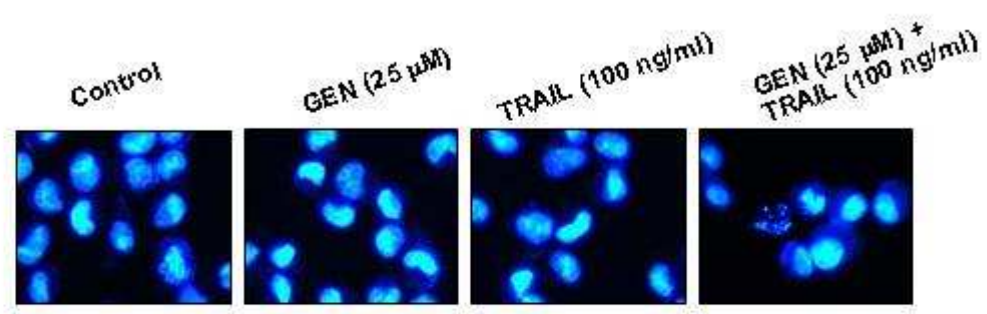

Fig. 1. Enhancement of TRAIL-induced apoptosis and loss of MMP by genistein in hepatocellular carcinoma Hep3B cells. (A) Cells were seeded at $1 \times 10^{5}$ cells $/ \mathrm{ml}$, and treated with the indicated concentrations of genistein, TRAIL, or genistein plus TRAIL for $24 \mathrm{hr}$. To quantify the degree of apoptosis, the cells were collected and stained with PI for flow cytometry analysis. The profile represents the increase of sub-G1 population and each point represents the mean of two independent experiments. (B) Cells grown under the same conditions as (A) were stained with JC-1 and then incubated at $37^{\circ} \mathrm{C}$ for 20 min, after which the mean JC-1 fluorescence intensity was detected using a flow cytometer. Results are expressed as percentage of two separate experiments. (C) To investigate morphological changes of nuclei, cells grown under the same conditions as (A) were stained with DAPI solution. Stained nuclei were then observed under a fluorescence microscope using a blue filter. Magnification, $\times 400$.

nal kinase (JNK), extracellularly responsive kinase (ERK) 및 p38 MAPK 특이적 억제제인 SP600125, PD98059 및 SB203580 과 Akt 경로 억제제인 LY294002를 선처리한 후, Hep3B 세포 의 생존율을 비교하였다. Fig. 2A에서 알 수 있듯이 Hep3B 세포의 생존에 큰 영향을 미치지 않는 4 가지 억제제의 선처리 조건에서, JNK, ERK 및 AKT 억제제인 SP600125, PD98059 및 LY294002는 TRAIL과 genistein 동시 처리에 의한 생존율 의 저하에 큰 영향을 미치지 않았다. 그러나 p38 MAPK 저해 제인 SB203580이 동시에 처리된 경우, Hep3B 세포의 생존율 이 매우 저하되었다(Fig. 2A). 따라서 p38 MAPK 활성 저하가 TRAIL과 genistein 동시 처리에 의한 apoptosis 유도를 더욱 증가시킬 것으로 추정되어 동일 조건에서 apoptosis 유도의 정도를 비교한 결과, SB203580이 선처리된 조건에서 TRAIL과 genistein이 처리된 배지에서 배양된 Hep3B 세포의 apoptosis 가 매우 높게 유발되었다(Fig. 2B). 이러한 p38 MAPK 활성 억제제와 TRAIL 및 genistein 동시 처리에 의한 apoptosis 유
도 증가의 정도를 재확인하기 위하여 전형적인 apoptosis가 유도된 세포에서 관찰되는 DNA 단편화 및 염색질 응축의 정 도를 관찰하였다. Fig. 3A 및 B에서 알 수 있듯이 SB203580과 TRAIL 및 genistein의 동시 처리에 의하여 apoptosis가 거의 유발되지 않는 조건에서 배양된 Hep3B 세포에 SB203580, TRAIL 및 genistein 3가지를 동시에 처리하였을 경우, DNA의 단편화와 염색질 응축 현상 및 전체적인 세포의 형태변형이 동반되었음을 관찰할 수 있었다. 이는 TRAIL과 genistein 동 시 처리에 의한 apoptosis 유도에 p38 MAPK 신호 경로가 매 우 중요하게 관여하고 있음을 보여 주는 결과이다.

TRAll과 genistein에 의한 미토콘드리아 기능 손상에 미 치는 $\mathrm{p} 38 \mathrm{MAPK}$ 의 영향

다음은 TRAIL과 genistein에 의한 apoptosis 유도에 미치는 몇 가지 주요 apoptosis 조절인자들의 발현 변화에 미치는 p38 $\mathrm{MAPK}$ 의 영향을 조사하기 위하여, 상기와 동일 조건에서 배 
(A)

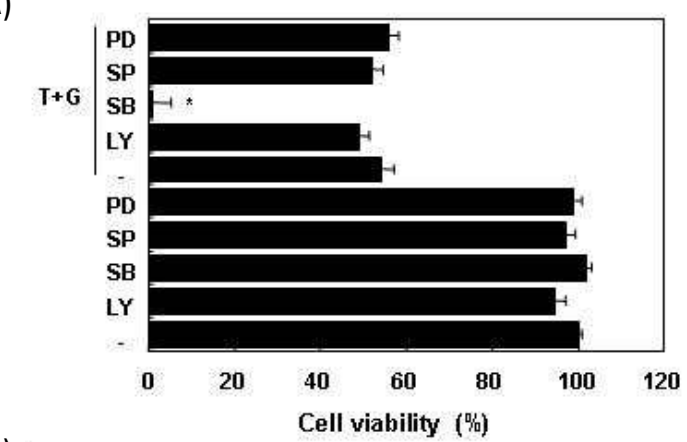

(B)

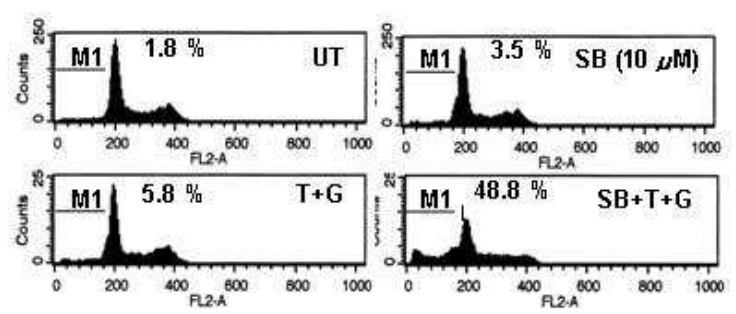

Fig. 2. Effects of MAPKs inhibition on genistein plus TRAIL-induced growth inhibition and apoptosis in Hep3B cells. Cells were treated with LY294002 $(10 \mu \mathrm{M})$, SP600125 (20 $\mu \mathrm{M})$, PD98059 $(50 \mu \mathrm{M})$, and SB203580 $(10 \mu \mathrm{M})$ for $1 \mathrm{hr}$ before combined treatment for $8 \mathrm{hr}$. (A) Cell viabilities were determined by MTT assay. Each point represents the mean $\pm \mathrm{SD}$ of three independent experiments. The significance was determined using Student's $t$-test $\left({ }^{*} p<0.05\right.$ vs. genistein plus TRAIL). (B) To quantify the degree of apoptosis, the cells were collected and stained with PI for flow cytometry analysis. The profile represents the increase of sub-G1 population and each point represents the mean of two independent experiments.

양된 Hep3B 세포를 대상으로 Bcl-2 family에 속하는 주요 인 자 및 cytochrome $c$ 의 발현 변화를 조사하였다. Fig. $4 \mathrm{~A}$ 에 나 타낸 결과에서 알 수 있듯이, apoptosis 유도에서 extrinsic 경 로와 intrinsic 경로의 매개체로 작용하는 Bid의 발현이 TRAIL 및 genistein 복합 처리군과 SB203580 단독 처리군에서 약간 감소된 반면 3 가지가 동시에 처리된 경우 total Bid의 발현이 거의 관찰되지 않아 truncation 형태인 tBid로 모두 전환되었 음을 알 수 있었다. 아울러 pro-apoptotic 단백질인 Bax의 발현 이 TRAIL, genistein 및 SB203580 복합 처리군에서 매우 증가 된 반면, anti-apoptotic 단백질인 Bcl-2의 발현은 매우 감소되 어 $\mathrm{Bcl}-2$ 에 비하여 상대적인 $\mathrm{Bax}$ 의 발현이 크게 증가되었고, 세포질 내의 cytochrome $c$ 발현이 매우 증가되었음을 알 수 있었다. 아울러 $\mathrm{MMP}$ 의 손실 정도가 3가지 동시 처리군에서 매우 증가되어(Fig. 4B), p38 MAPK 활성의 억제가 TRAIL 및 genistein의 복합 처리군에 의한 extrinsic 및 intrinsic 경로 활
(A)

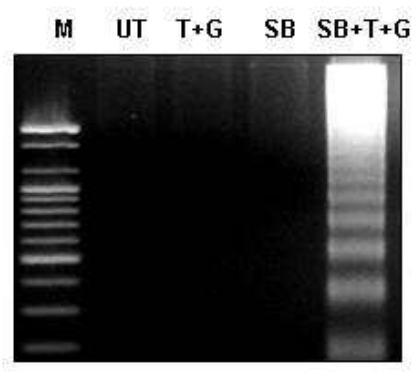

(B)

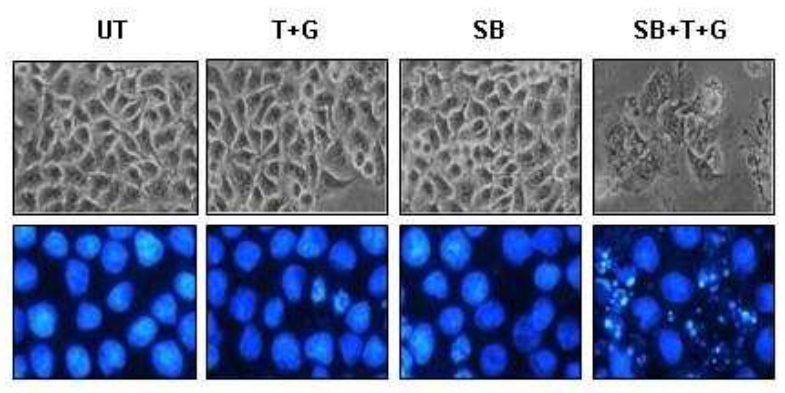

Fig. 3. Effects of p38 MAPK inhibition on apoptosis induction by genistein plus TRAIL in Hep3B cells. Cells were treated with SB203580 $(10 \mu \mathrm{M})$ for $1 \mathrm{hr}$ before combined treatment for $8 \mathrm{hr}$. (A) For analysis of DNA fragmentation, genomic DNA was extracted, electrophoresed in a $1.6 \%$ agarose gel, and visualized by EtBr staining. (B) The cell morphology was visualized by an inverted microscope (Magnification, X200), or by staining the cells with DAPI solution after fixing. Stained nuclei were then observed under a fluorescent microscope using a blue filter (Magnification, X400).

성을 크게 촉진시켜 apoptosis 유도를 증가시켰을 것으로 추 정된다.

TRAll과 genistein 동시 처리군에서 caspase 활성 미치 는 $\mathrm{p} 38 \mathrm{MAPK}$ 의 영향

이상에서 관찰된 p38 MAPK 저해제에 의한 TRAIL 및 genistein의 복합 처리군의 extrinsic 및 intrinsic 경로 활성 촉진 가능성의 여부를 조사하기 위하여 extrinsic 및 intrinsic 경로 의 활성 개시에 핵심적으로 관여하는 caspase-8 및 -9 와, 대표 적인 effector caspase인 caspase-3의 발현 변화를 조사하였다. Fig. 5의 결과에서 알 수 있듯이, SB203580 단독 처리군 및 TRAIL과 genistein 복합 처리군에서 전혀 관찰되지 않았던 활성형 caspase-8의 발현이 SB203580, TRAIL 및 genistein 복 합 처리군에서 관찰되었으며, 비활성형 caspase-9의 발현도 3 가지 복합 처리군에서 매우 감소되었다. 아울러 SB203580 단 독 처리군 및 TRAIL과 genistein 복합 처리군에서는 관찰되지 않았던 활성형 caspase-3의 발현도 3 가지 복합 처리군에서 매 
(A)

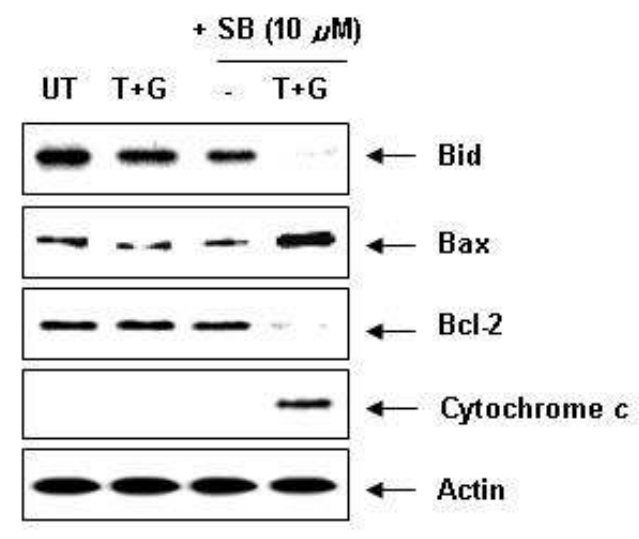

(B)

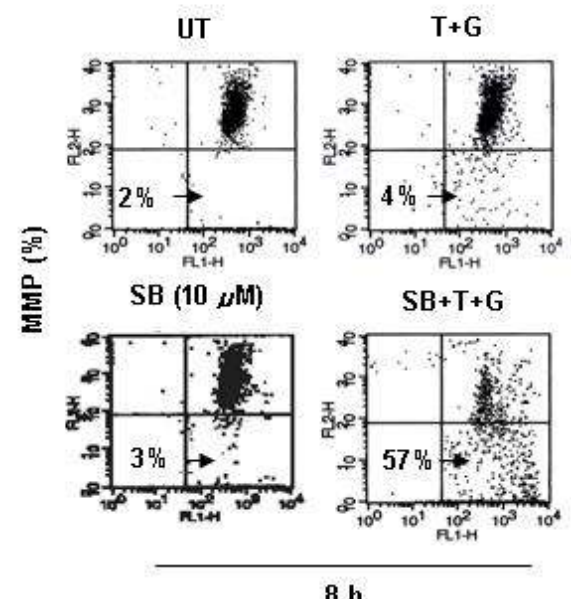

Fig. 4. Effects of p38 MAPK inhibition on the mitochondrial dysfunction induced by genistein plus TRAIL in Hep3B cells. Cells were treated with SB203580 $(10 \mu \mathrm{M})$ for $1 \mathrm{hr}$ before combined treatment for $8 \mathrm{hr}$. (A) Equal amounts of cell lysates (30 $\mu \mathrm{g})$ were resolved by SDS-polyacrylamide gels, transferred to nitrocellulose membranes, and probed with the indicated antibodies. Actin was used as an internal control. A representative study is shown, and two additional experiments yielded similar results. (B) Cells grown under the same conditions as (A) were stained with JC-1 and then incubated at $37^{\circ} \mathrm{C}$ for $20 \mathrm{~min}$, after which the mean JC-1 fluorescence intensity was detected using a flow cytometer. Results are expressed as percentage two separate experiments.

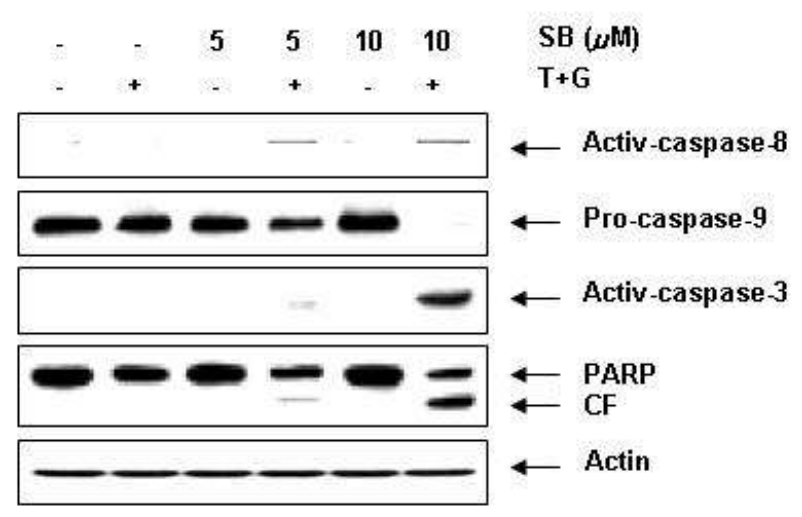

Fig. 5. Effects of p38 MAPK inhibition on the caspase activation induced by genistein plus TRAIL in Hep3B cells. Cells were treated with SB203580 (5 or $10 \mu \mathrm{M})$ for $1 \mathrm{hr}$ before combined treatment for $8 \mathrm{hr}$. Equal amounts of cell lysates $(30 \mu \mathrm{g})$ were resolved by SDS-polyacrylamide gels, transferred to nitrocellulose membranes, and probed with the indicated antibodies. Actin was used as an internal control. CF, cleavage form.

우 증가되었으며, 활성형 caspase-3의 표적 단백질인 PAPR의 단편화도 3 가지 복합 처리군에서만 관찰되었다. 이상의 결과 는 TRAIL과 genistein에 의한 extrinsic 및 intrinsic 경로가 연 계된 apoptosis 유도가 p38 MAPK 활성저해로서 더욱 촉진되 었음을 의미한다.

\section{고 찰}

TRAIL은 최근 알려진 apoptosis 유도 인자 중의 하나로서 정상세포에서는 세포독성을 보이지 않는 반면, 암세포, 형질 전환된 세포 또는 바이러스에 감염된 세포 등에서 apoptosis 를 유발할 수 있기 때문에 이를 활용한 항암전략이 큰 관심을 모으고 있다[3,12]. 그러나 인체간암세포를 포함한 몇몇 암세 포에서 TRAIL에 대한 저항성을 가지는 것으로 보고되면서 TRAIL의 활용에 관한 새로운 접근이 요구되어지고 있는데 [20,28,33,38], 이러한 TRAIL 저항성의 원인으로 많은 apoptosis 조절 유전자들의 돌연변이나 과발현 등으로 추정되고 있다 $[4,19,23,35]$. 본 연구에서는 TRAIL 저항성 Hep3B 세포에서 대두의 대표적인 생리활성 물질로 알려진 isoflavonoid의 일 종인 genistein이 TRAIL에 의한 apoptosis 유도를 매우 촉진 할 수 있음을 제시하고자 한다. 이를 위하여 세포독성을 나타 내지 않는 범위의 genistein 처리 조건에서 TRAIL에 의한 apoptosis가 genistein의 처리 농도 증가에 따라 큰 폭으로 상 승하였음을 제시하였고(Fig. $1 \mathrm{~A}$ 및 C), 이는 미토콘드리아 기 능의 손상과 연관이 있음을 알 수 있었다(Fig. 1B).

TRAIL 저항성 극복을 위한 genistein의 활용 방안에 관한 연구 중, Lee 등[25]은 자궁경부암세포에서 genistein에 의한 TRAIL 저항성 극복이 ERK 경로의 비활성화와 연관되어 있음 을 보고한 바 있으며, TRAIL 저항성 폐암세포에서 genistein 은 Akt의 비활성화를 유도함으로서 TRAIL 유도 apoptosis 활 성을 상승시킬 수 있는 것으로 보고된 바 있다[27]. 본 연구실 
의 선행 결과에서 genistein에 의한 간암세포의 TRAIL 저항성 극복에 p38 MAPK 연관 가능성을 제시하였지만[14], MAPKs 또는 PI3K/Akt 경로 관련 총괄적인 비교 연구는 이루어진 바 없다. 따라서 동일 조건에서 이들 경로의 연관 가능성에 대한 비교를 하기 위하여 3가지 MAPKs 저해제 및 Akt 활성 저해제 가 genistein 및 TRAIL 복합처리에 미치는 영향을 조사한 결 과, p38 MAPK 활성을 저해하였을 경우, genistein과 TRAIL 복합 처리에 의한 $\mathrm{Hep} 3 \mathrm{~B}$ 세포의 생존율을 극단적으로 저해하 였으며, 이러한 p38 MAPK 활성의 저해는 genistein 및 TRAIL 복합처리에 의한 apoptosis 활성을 매우 증가시켰음을 확인하 였다(Fig. 2 및 3). 즉 최소한 genistein 및 TRAIL 복합처리에 의한 apoptosis 유도활성에는 Hep3B 세포에서 p38 MAPK 경 로가 중요하게 작용하고 있음을 알 수 있었다.

한편 그동안 보고된 genistein에 의한 암세포의 apoptosis 유도에는 현재까지 잘 알려진 apoptosis의 extrinsic 및 intrinsic 두 가지 주요 경로를 모두 경유하는 것으로 보고되어지 고 있는데[18], Bid의 truncation (tBid)은 두 경로의 연결에 필수적으로 관여하는 pro-apoptotic 단백질이다. 따라서 genistein과 TRAIL의 동시 처리에 의한 apoptosis 유도에서도 $\mathrm{p} 38 \mathrm{MAPK}$ 의 경로를 차단할 경우 두 경로가 동시에 관여할 것으로 기대되어 $\mathrm{Bid}$ 의 발현 변화를 조사한 결과, $\mathrm{p} 38 \mathrm{MAPK}$ 저해제, genistein 그리고TRAIL이 동시에 처리된 조건에서 배 양된 $\mathrm{Hep} 3 \mathrm{~B}$ 세포에서 total $\mathrm{Bid}$ 의 발현이 완벽하게 사라져 tBid로 전환되었을 가능성을 보여주었다(Fig. 4A). 아울러 동 일 조건에서 관찰된 $\mathrm{Bax}$ 의 발현 증가와 $\mathrm{Bcl}-2$ 의 발현 감소는 미토콘드리아의 $\mathrm{MMP}$ 손실에 대한 원인으로 작용하였을 것 으로 생각되며, 이러한 $\mathrm{MMP}$ 의 손실로 정상적인 미토콘드리 아의 기능을 저해함으로서 cytochrome 아 미토콘드리아에서 세포질로의 유출이 촉진되었음을 알 수 있었다(Fig. 4). 또한 genistein과 TRAIL이 동시에 처리된 조건에서 $\mathrm{p} 38 \mathrm{MAPK}$ 활 성의 차단으로 인한 apoptosis 유발 과정에 extrinsic 및 intrinsic 경로가 모두 관여하였다면, 각각의 경로를 촉진시키는 데 관여하는 caspase의 활성이 증가되었을 것이므로 몇 가지 주요 caspase의 발현 변화를 조사한 결과, p38 MAPK 저해제, genistein 및 TRAIL이 복합 처리된 조건에서 배양된 Hep3B 세포에서 extrinsic 및 intrinsic의 개시에 담당하는 caspase-8 및 -9의 활성이 증가되었음을 확인하였고, 아울러 두 caspase 의 down-stream caspase인 caspase-3 활성형의 발현이 매우 증가되었다(Fig. 5). 또한 caspase-3의 표적 단백질이며 apoptosis가 일어난 세포에서 단편화가 관찰되는 PARP 단백질 역 시 동일 조건에서 단편화가 유도되었음을 확인하였다(Fig. 5).

최근 면역세포, 신경교세포, 혈구암세포, 자궁경부암세포, 간암세포 및 대장암세포 등을 이용한 연구들에서 TRAIL에 의하여 유도되는 apoptosis에 MAPKs 신호 전달계 중, p38 $\mathrm{MAPK}$ 경로가 직접적으로 관여하고 있음이 보고되어져 왔다 $[1,2,5,22,24,37,39]$. 특히 TRAIL 저항성 유방암세포에서 TNF
에 의하여 유도되는 apoptosis 활성이 p38 MAPK의 활성 억 제로 매우 증가되는 것으로 나타났으며, endotoxin에 의한 혈 장 용해성 TRAIL의 발현을 증가에 p38 MAPK가 관여하고 있음이 보고된 바 있다[37]. 이러한 결과들과 본 연구의 결과 는 암세포의 종류에 따른 약간의 차이는 있겠지만, p38 MAPK 신호계가 TRAIL 저항성에 연관된 apoptosis 조절에 직접 관여하고 있음을 암시하여 주는 것이다. 그러나 일반적 으로 genistein에 의한 암세포의 증식억제는 세포주기 G2/M arrest와 연관성이 있는 점으로 미루어, 세포주기 교란과 연관 된 $\mathrm{p} 38 \mathrm{MAPK}$ 의 역할에 대해서는 추후 더 구체적인 연구가 요구된다.

\section{감사의 글}

이 논문은 2010년도 정부(교육과학기술부)의 재원으로 한 국연구재단의 지원을 받아 수행된 기초연구사업임(20100008843 및 2011-0003305).

\section{References}

1. Abdollahi, T. 2004. Potential for TRAIL as a therapeutic agent in ovarian cancer. Vitam Horm 67, 347-364.

2. Abdollahi, T., N. M. Robertson, A. Abdollahi, and G. Litwack. 2005. Inhibition of TRAIL-induced apoptosis by IL-8 is mediated by the p38-MAPK pathway in OVCAR3 cells. Apoptosis 10, 1383-1393.

3. Ashkenazi, A., R. C. Pai, S. Fong, S. Leung, D. A. Lawrence, S. A. Marsters, C. Blackie, L. Chang, A. E. McMurtrey, A. Hebert, L. DeForge, I. L. Koumenis, D. Lewis, L. Harris, J. Bussiere, H. Koeppen, Z. Shahrokh, and R. H. Schwall. 1999. Safety and antitumor activity of recombinant soluble Apo2 ligand. J. Clin. Invest. 104, 155-162.

4. Chawla-Sarker, M., S. I. Bae, F. J. Reu, B. S. Jacobs, D. J. Lindner, and E. C. Borden. 2004. Downregulation of Bcl-2, FLIP or IAPs (XIAP and survivin) by siRNAs sensitizes resistant melanoma cells to Apo2L/TRAIL-induced apoptosis. Cell Death Differ. 11, 915-923.

5. Choi, K., S. Song, and C. Choi. 2008. Requirement of caspases and p38 MAPK for TRAIL-mediated ICAM-1 expression by human astroglial cells. Immunol. Lett. 117, 168-173.

6. Choi, Y. H., W. H. Lee, K. Y. Park, and L. Zhang. 2000. p53-independent induction of p21 (WAF1/CIP1), reduction of cyclin B1 and G2/M arrest by the isoflavone genistein in human prostate carcinoma cells. Jpn. J. Cancer Res. 91, 164-173.

7. Choi, Y. H., L. Zhang, W. H. Lee, and K. Y. Park. 1998. Genistein-induced G2/M arrest is associated with the inhibition of cyclin B1 and the induction of p21 in human breast carcinoma cells. Int. J. Oncol. 13, 391-396.

8. Cohen, J. H., A. R. Kristal, and J. L. Stanford. 2000. Fruit and vegetable intakes and prostate cancer risk. J. Natl. 
Cancer Inst. 5, 61-68.

9. Conklin, C. M., J. F. Bechberger, D. McFabe, N. Guthrie, E. M. Kurowska, and C. C. Naus. 2007. Genistein and quercetin increase connexin 43 and suppress growth of breast cancer cells. Carcinogenesis 28, 93-100.

10. Gonzalez-Guerrico, A. M. and M. G. Kazanietz. 2005. Phorbol ester-induced apoptosis in prostate cancer cells via autocrine activation of the extrinsic apoptotic cascade: a key role for protein kinase C delta. J. Biol. Chem 280, 38982-38991.

11. Guicciardi, M. E., S. F. Bronk, N. W. Werneburg, and G. J. Gores. 2007. cFLIPL prevents TRAIL-induced apoptosis of hepatocellular carcinoma cells by inhibiting the lysosomal pathway of apoptosis. Am J. Physiol. Gastrointest Liver Physiol. 292, 1337-1346.

12. Hao, C., J. H. Song, B. His, J. Lewis, D. K. Song, K. C. Petruk, D. L. Tyrrell, and N. M. Kneteman. 2004. TRAIL inhibits tumor growth but is nontoxic to human hepatocytes in chimeric mice. Cancer Res. 64, 8502-8506.

13. Jin, C. Y., C. Park, J. Cheong, B. T. Choi, T. H. Lee, J. D. Lee, W. H. Lee, G. Y. Kim, C. H. Ryu, and Y. H. Choi. 2007. Genistein sensitizes TRAIL-resistant human gastric adenocarcinoma AGS cells through activation of caspase-3. Cancer Lett 257, 56-64.

14. Jin, C. Y., C. Park, G. Y. Kim, S. J. Lee, W. J. Kim, and Y. H. Choi. 2009. Genistein enhances TRAIL-induced apoptosis through inhibition of p38 MAPK signaling in human hepatocellular carcinoma Hep3B cells. Chem Biol. Interact. 180, 143-150.

15. Jin, C. Y., C. Park, S. K. Moon, G. Y. Kim, T. K. Kwon, S. J. Lee, W. J. Kim, and Y. H. Choi. 2009. Genistein sensitizes human hepatocellular carcinoma cells to TRAIL-mediated apoptosis by enhancing Bid cleavage. Anticancer Drugs 20, 713-722.

16. Kang, J. L., H. W. Lee, H. J. Kim, H. S. Lee, V. Castranova, C. M. Lim, and Y. Koh. 2005. Inhibition of SRC tyrosine kinases suppresses activation of nuclear factor- $\kappa B$, and serine and tyrosine phosphorylation of IкB-a in lipopolysaccharide-stimulated raw 264.7 macrophages. J. Toxicol. Environ. Health 68, 1643-1662.

17. Kim, H., E. H. Kim, Y. W. Eom, W. H. Kim, T. K. Kwon, S. J. Lee, and K. S. Choi. 2006. Sulforaphane sensitizes tumor necrosis factor-related apoptosis-inducing ligand (TRAIL)-resistant hepatoma cells to TRAIL-induced apoptosis through reactive oxygen species-mediated up-regulation of DR5. Cancer Res. 66, 1740-1750.

18. Kim, S. H., S. H. Kim, S. C. Lee, and Y. S. Song. 2009. Involvement of both extrinsic and intrinsic apoptotic pathways in apoptosis induced by genistein in human cervical cancer cells. Ann. N Y Acad Sci. 1171, 196-201.

19. Kim, Y. H., J. W. Park, J. Y. Lee, and T. K. Kwon. 2004. Sodium butyrate sensitizes TRAIL-mediated apoptosis by induction of transcription from the DR5 gene promoter through Sp1 sites in colon cancer cells. Carcinogenesis 25, 1813-1820.

20. Kim, Y. S., R. F. Schwabe, T. Qian, J. J. Lemasters, and D.
A. Brenner. 2002. TRAIL-mediated apoptosis requires NF- $\kappa$ $B$ inhibition and the mitochondrial permeability transition in human hepatoma cells. Hepatology 36, 1498-1508.

21. Kischkel, F. C., D. A. Lawrence, A. Chuntharapai, P. Schow, K. J. Kim, and A. Ashkenazi. 2000. Apo2L/TRAIL-dependent recruitment of endogenous FADD and caspase-8 to death receptors 4 and 5. Immunity 12, 611-620.

22. Lamy, V., S. Bousserouel, F. Gossé, C. Minker, A. Lobstein, and F. Raul. 2011. Lupulone triggers p38 MAPK-controlled activation of p53 and of the TRAIL receptor apoptotic pathway in human colon cancer-derived metastatic cells. Oncol. Rep. 26, 109-114.

23. LeBlanc, H., D. Lawrence, E. Varfrolomeev, K. Totpal, J. Morlan, P. Schow, S. Fong, R. Schwall, D. Sinicropi, and A. Ashkenazi. 2002. Tumor-cell resistance to death receptor-induced apoptosis through mutational inactivation of the proapoptotic Bcl-2 homolog Bax. Nat. Med 8, 274-281.

24. Lee, J., J. S. Shin, J. Y. Park, D. Kwon, S. J. Choi, S. J. Kim, and I. H. Choi. 2003. p38 mitogen-activated protein kinase modulates expression of tumor necrosis factor-related apoptosis-inducing ligand induced by interferon-gamma in fetal brain astrocytes. J. Neurosci. Res. 74, 884-890.

25. Lee, M. W., J. H. Bach, H. J. Lee, D. Y. Lee, W. S. Joo, Y. S. Kim, S. C. Park, K. Y. Kim, W. B. Lee, and S. S. Kim. 2005. The activation of ERK1/2 via a tyrosine kinase pathway attenuates trail-induced apoptosis in HeLa cells. Cancer Invest 23, 586-592.

26. Lub-de Hooge, M. N., S. de Jong, C. Vermot-Desroches, J. E. Tulleken, E. G. de Vries, and J. G. Zijlstra. 2004. Endotoxin increases plasma soluble tumor necrosis factor-related apoptosis-inducing ligand level mediated by the p38 mitogen-activated protein kinase signaling pathway. Shock 22, 186-188.

27. Park, J. H., E. J. Oh, Y. H. Choi, C. D. Kang, H. S. Kang, D. K. Kim, K. I. Kang, and M. A. Yoo. 2001. Synergistic effects of dexamethasone and genistein on the expression of Cdk inhibitor p21WAF1/CIP1 in human hepatocellular and colorectal carcinoma cells. Int. J. Oncol. 18, 997-1002.

28. Pei, Z., L. Chu, W. Zou, Z. Zhang, S. Qiu, R. Qi, J. Gu, C. Qian, and X. Liu. 2004. An oncolytic adenoviral vector of Smac increases antitumor activity of TRAIL against HCC in human cells and in mice. Hepatology 39, 1371-1381.

29. Pinski, J., Q. Wang, M. L. Quek, A. Cole, J. Cooc, K. Danenberg, and P. V. Danenberg. 2006. Genistein-induced neuroendocrine differentiation of prostate cancer cells. Prostate 66, 1136-1143.

30. Raffoul, J. J., Y. Wang, O. Kucuk, J. D. Forman, F. H. Sarkar, and G. G. Hillman. 2006. Genistein inhibits radiation-induced activation of NF- $\mathrm{kB}$ in prostate cancer cells promoting apoptosis and G2/M cell cycle arrest. BMC Cancer 6, 107.

31. Ravindranath, M. H., S. Muthugounder, N. Presser, and S. Viswanathan. 2004. Anticancer therapeutic potential of soy isoflavone, genistein. AdV. Exp. Med Biol. 546, 121-165.

32. Sarkar, F. H., S. Adsule, S. Padhye, S. Kulkarni, and Y. Li. 2006. The role of genistein and synthetic derivatives of iso- 
flavone in cancer prevention and therapy. Mini Rev. Med Chem 6, 401-407.

33. Shankar, S, and R. Srivastava. 2004. Enhancement of therapeutic potential of TRAIL by cancer chemotherapy and irradiation: mechanisms and clinical implications. Drug Resist Updat 7, 139-156.

34. Srivastava, R. K. 2001. TRAIL/Apo-2L: mechanisms and clinical applications in cancer. Neoplasia 3, 535-546.

35. Van Geelen, C. M., E. G. de Vries, and S. de Jong. 2004. Lessons from TRAIL-resistance mechanisms in colorectal cancer cells: paving the road to patient-tailored therapy. Drug Resist Updat 7, 345-358.

36. Wang, C., T. Chen, N. Zhang, M. Yang, B. Li, X. Lü, X. Cao, and C. Ling. 2009. Melittin, a major component of bee venom, sensitizes human hepatocellular carcinoma cells to tumor necrosis factor-related apoptosis-inducing ligand (TRAIL)-induced apoptosis by activating CaMKII-TAK1JNK/p38 and inhibiting IкBa kinase-NFkB. J. Biol. Chem
284, 3804-3813.

37. Weldon, C. B., A. P. Parker, D. Patten, S. Elliott, Y. Tang, D. E. Frigo, C. M. Dugan, E. L. Coakley, N. N. Butler, J. L. Clayton, J. Alam, T. J. Curiel, B. S. Beckman, B. M. Jaffe, and M. E. Burow. 2004. Sensitization of apoptotically-resistant breast carcinoma cells to TNF and TRAIL by inhibition of p38 mitogen-activated protein kinase signaling. Int. J. Oncol. 24, 1473-1480.

38. Yamanaka, T., K. Shiraki, K. Sugimoto, T. Ito, K. Fujikawa, M. Ito, K. Takase, M. Moriyama, T. Nakano, and A. Suzuki. 2000. Chemotherapeutic agents augment TRAIL-induced apoptosis in human hepatocellular carcinoma cell lines. Hepatology 32, 482-490.

39. Zauli, G., E. Rimondi, V. Nicolin, E. Melloni, C. Celeghini, and P. Secchiero. 2004. TNF-related apoptosis-inducing ligand (TRAIL) blocks osteoclastic differentiation induced by RANKL plus M-CSF. Blood 104, 2044-2050.

\section{초록 : 인체간암세포에서 genistein의 TRAIL에 의한 apoptosis 유도 상승효과에서 미치는 p38 MAPK signaling pathway의 영향

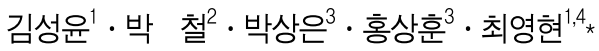 \\ ( ${ }^{1}$ 동의대학교 대학원 바이오물질제어학과(BK21 program) 및 블루바이오소재개발센터, ${ }^{2}$ 충북대학교 의과대 학 의과학연구소, 동의대학교 한의과대학 ${ }^{3}$ 내과학교실, ${ }^{4}$ 생화학교실 및 한의학연구소)}

TRAIL은 다양한 암세포에서 apoptosis를 유발하는 것으로 알려져 있으나 간암세포를 포함한 일부 암세포에서 TRAIL 저항성이 획득된 것으로 보고되어지고 있다. 대두의 대표적인 생리활성 물질인 isoflavonoid계열 genistein은 이미 많은 암세포에서 apoptotic 효능을 가진 것으로 알려져 있으나 TRAIL에 의한 apoptosis 유도에 미치 는 영향과 기전에 대한 연구는 여전히 미비한 실정이다. 본 연구에서는 TRAIL 저항성을 가진 Hep3B 간암세포에 서 TRAIL에 의한 apoptosis 유도를 genistein이 더욱 상승시킬 수 있음을 보고하고자 한다. 본 연구의 결과에 의하면, Hep3B 세포에 세포독성을 보이지 않는 범위의 genistein에 의한 TRAIL 유도 apoptosis 상승효과는 미토 콘드리아의 기능 손상과 연관성이 있었다. 또한 genistein과 TRAIL 복합처리에 의한 apoptosis 유도는 p38 MAPK 활성 저하로 더욱 상승하였으며, 이는 Bid의 truncation 증가, pro-apoptotic 단백질인 Bax의 발현 증가와 anti-apoptotic Bcl-2의 발현 감소 및 미토콘드리아에서 세포질로의 cytochrome $c$ 유출의 증가와 연관성이 있었다. 또한 p38 MAPK 억제제는 genistein 및 TRAIL 복합처리에 의한 caspase의 활성 증가와 PARP 단백질의 단편화 를 촉진시켰으며, 이는 미토콘드리아의 기능적 손상 증가에 의한 것임을 알 수 있었다. 따라서 본 연구의 결과는 genistein이 TRAIL에 의한 apoptosis 유도를 효과적으로 증가시킬 수 있으며, 이러한 과정이 p38 MAPK 의존적 으로 이루어짐을 알 수 있었다. 